\title{
Primary production and estimation of potential fish yield in Lake Cocibolca, Nicaragua
}

\author{
E. Hooker, N. Chow-Wong, K. Rivas, R. Erikson, I. Ahlgren and G. Ahlgren
}

\section{Introduction}

Lake Cocibolca (L. Nicaragua), the largest lake in the tropical Americas with a surface area of 7,600 $\mathrm{km}^{2}$, is still relatively unaffected by human impact when compared to neighboring Lake Xolotlán. However, little limnological research has been published on this valuable and important Nicaraguan natural resource. Data on fish biology and general limnological features were published by THORSON (1976); only a few primary production measurements were made in the early 1980 s using the oxygen method, giving primary production values of about $4-7 \mathrm{~g} \mathrm{O}_{2} \mathrm{~m}^{-2}$ day $^{-1}$ (KATUNIN et al. 1983, ERIKsoN unpublished).

Two of the principle factors controlling primary production in lakes, excepting nutrients, are light penetration and mixing depth. Light penetration in the water column is controlled by the presence of phytoplankton and their pigments, suspended organic and inorganic detritus, and dissolved colored organic matter (TAlLING et al. 1973, BanNister 1974, AHI.GREN \& ABEGAZ 1993). 'T'he ratio between light extinction caused by algae versus the other agents is a major factor determining the primary productivity of a lake. Maximum primary production occurs where light extinction results principally from the presence of algal pigments. Conversely, increasing light extinction caused by other agents will inevitably reduce primary production.

A SAREC-SIDA project, started in 1996 and focusing on the lake food chain, hypothesized that a greater fraction of primary production is transferred to L. Cocibolca fish production than to L. Xolotlán fish production. Models that use phytoplankton primary production as the main controlling variable for predicting fish yield in lakes have resulted in more successful predictions than many other methods (Melack 1976, Oglesby 1977, Lowe-McConnell 1987, Downivg et al. 1990, KNÖSCHE \& BarTHFL.MES 1998). Therefore, it is important to make accurate primary production measurements. A high correlation between daily photosynthesis and pro- duction of fish fry in ponds has also been observed (WOLNY \& GRYGiereK 1972). Despite the proven relationships between primary production and fish yield, primary production is seldom measured by fish biologists.

The ratio of fish yield to primary production is expected to be higher in tropical than in temperate lakes. However, the estimated fish yield of $0.5 \mathrm{~kg} \mathrm{ha}^{-1}$ year 'from L. Cocibolca (COLE 1976) is very low when compared to the mean of several African lakes, $60 \mathrm{~kg} \mathrm{ha}{ }^{\prime}$ year $^{-1}$ (MFi.ACK 1976). A lack of large boats and effective fishing gear make it difficult to fish in the open waters of wind-exposed $L$. Cocibolca (Cot. 1976); fishing was most probably restricted to shore areas, so that only a small fraction of the potential fish was harvested. MELACK (1976) also showed that the fish yield of lakes in Africa and India increased exponentially as primary production increased linearly. He hyporhesized that herbivorous fish become increasingly numerous in more eutrophic waters. Hence, a shorter food-chain leads to higher efficiency in energy transfer along the food chain. However, changes in phytoplankton species composition to the less edible and less nutritious cyanobacteria (AHLGRFN et al. 1992) tend to counteract this effect.

The purpose of this study is to:

- present light measurements and data on primary production, nutrients and phytoplankton from L. Cocibolca, Nicaragua;

- calculate the fraction of photosynthetic available radiation (PAR) absorbed by phytoplankton in L. Cocibolca;

- estimate the potential fish production of $\mathrm{L}$ Cocibolca based on primary production values.

\section{Methods}

Primary production was measured by the usual bottle-technique described in detail in AHLCREN (1988b). Filters were treated overnight with a tissucsolubilizer (BTS-450, Beckman) before adding the 
scintillation cocktail (PUGił 1973). Integral primary production per unit surface area ( $2 A)$ was corrected with the dark vahues. Exposure time varied from 1-2 $\mathrm{h}$ and daily production was calculated by multiplying the hourly production rate by a factor of 9 (TALLING 1965, ERIKSON et al. 1997). Light measurements were performed with a LI-189 quantum meter (LI-COR Inc., Lincoln, Nebraska).

Chlorophyll was analyzed using warm extraccion in ethanol (Nusch 1980). Chemical analyses wert performed as per AHLGREN \& AHLGREN (1976), e.g. dissolved inorganic $\mathrm{N}\left(\mathrm{DIN}=\mathrm{NH}_{4}-\mathrm{N}+\mathrm{NO}_{3}-\mathrm{N}\right)$, total $\mathrm{N}$ (Kjeldahl-N $+\mathrm{NO}_{3}$ ), dissolved inorganic phosphorus (DIP) and total $\mathrm{P}$ (Tot-P).

\section{Results and discussion}

Thirteen primary production measurements were performed using the C14 method in $\mathrm{L}$. Cocibolca between 1990-1998, seven at the end of the dry season (April) and six at the end of the wet season (late October to early November) (Table 1). All measurements show typical optimum curves, with the optimum depths varying from $0.25-1.25 \mathrm{~m}$. Because of the large, exposed surface area of L. Cocibolca, the primary production values are mainly of autochthonous origin. Annual temperatures do not exhibit much variation, $29 \pm 2^{\circ} \mathrm{C}$ (ERIKSON et al. 1997). Limited nutrient data from just five dry-season and two wet-season sampling dates showed moderately high $N$ and $P$ values: 610-740 $\mathrm{\mu g}$ total $\mathrm{N} \mathrm{L}^{\mathrm{l}}$ and 63-87 $\mu \mathrm{g}$ total $\mathrm{P}$ $\mathrm{L}^{-1}$. The available $\mathrm{P}$ (DIP) was high, 9-50 $\mathrm{gg}$ $\mathrm{L}^{-1}$, as was the available $\mathrm{N}$ (DIN), $13-25 \mu \mathrm{g} \mathrm{L^{-1 }}$. The ratio of rotal $N /$ total $P$ has been at about I0 for the past 2 years, 1997-1998, indicating that these two nutrients are well balanced.

The $\Sigma A$ values were two times higher during the dry season compared to the wet season over the last 2 years (Table 1) The greatest variation was 6 -fold, ranging from 0.50 to $3.1 \mathrm{~g} \mathrm{C} \mathrm{m}^{-1}$ day ${ }^{-1}$. Primary production at the optimum depth $\left(a_{o p u}\right)$ varied proportionately, whereas chlorophyll increased by only about $50 \%$ during the dry season compared to the wet season (Table 1). The basic reason for this differences is probably related to hydrological conditions. Unfortunately, few chemical data are available for the wet seasons. However, it should be noted that after heavy rain periods, the level of the lake is usually elevated by as much as $1 \mathrm{~m}$, which would cause a dilution in nutrients and by that a reduction in primary production. The two values of around $0.5 \mathrm{~g} \mathrm{C} \mathrm{m} \mathrm{m}^{-1}$ day $^{-1}$, recorded during the wet season 1997, are unusually low. It might be a mistake in some calculation factor which cannot be checked. The windy dry season also favored the more productive diatoms, whereas, during the wet season, the slowly growing cyanophytes and chlorophytes were dominant (RIVAS 1998, HOOKER unpublished).

The light attenuation coefficient $(\varepsilon)$ was also different for the two seasons, with lower values, indicating deeper light transmission, appearing toward the end of the wet season. The fraction of light absorbed by chlorophyll $(f)$ can only be approximated. Using the specific chlorophyll absorption constant $\left(k_{i}\right)$ of 0.025 (ERIKSON unpublished) and average chlorophyll concentrations for the dry and wet seasons of 22 and $15 \mathrm{mg} \mathrm{m}^{-3}$, respectively, we get $\mathrm{f}_{c}=\mathrm{k} \times \mathrm{Chl} / \mathrm{\varepsilon}=$ $0.025 \times 22 / 2=0.28$ vs. $0.025 \times 15 / 1.3=0.29$ for the dry and wet seasons, respectively. These results demonstrate that the effect of $f$ was similar in the two seasons. Theoretically, $\Sigma A$ has a value equal to the upper limit of photosynthesis in a system where chlorophyll absorbs $100 \%$ of the available light, multiplied by the $\mathrm{f}_{\mathrm{t}}$ (BANNISTER 1974, AHLGREN \& ABEgAz 1993). The upper limit seems to be around $8.8 \mathrm{~g} \mathrm{C} \mathrm{m}^{-1}$ day $^{-1}$ (TAll.ING et al. 1973). The L. Cocibolca values, thus, would be 0.28 or $0.29 \times 8.8=2.5$ $-2.6 \mathrm{~g} \mathrm{C} \mathrm{m}^{-2} \mathrm{day}^{-1}$, which are close to the values recorded in Table 1.

Productivity at the optimal depth, measured as assimilation number (AZ), i.e. production normalized to chlorophyll, was also higher during the dry season with mean values of $9 \mathrm{mg} \mathrm{C}$ mg $\mathrm{Ch}^{-1} \mathrm{~h}^{-1}$, compared to the wet season with mean values of $5 \mathrm{mg} \mathrm{C} \mathrm{mg} \mathrm{Ch}{ }^{-1} \mathrm{~h}^{1}$ (Table 1 ). In the rropics, a $P_{\text {max }}$ of up to $30 \mathrm{mg} \mathrm{O}, \mathrm{mg}$ $\mathrm{Ch}^{-1} \mathrm{~h}^{-1}$ has been recorded (TALLING et al. 1973), corresponding to an $\mathrm{AZ}$ value of $11 \mathrm{mg} \mathrm{C} \mathrm{mg}$ $\mathrm{Ch}^{-1} \mathrm{~h}^{-1}$, which is the same level recorded in $\mathrm{L}$. Cocibolca during the dry season. This value is higher than the maximum which is considered realistic in temperate Tasmania, $6.2 \mathrm{mg} \mathrm{C} \mathrm{mg}$ 
Table I. Primary production in Lake Cocibolca during the end of dry season and the end of wet season. Primary production per day is estimated by multiplying the hourly production with the factor 9 (TALLING 1965, ERIKSON et al. 1997). $a_{\text {opr }}$, primary production at the optimum depth; $z_{o p e}$, optimum depth; AZ, assimilation number, i.e. prim. production normalized to chlorophyll; $\varepsilon_{\text {tor }}$, extinction coefficient, $\Sigma A$, integral primary production.

\begin{tabular}{|c|c|c|c|c|c|c|}
\hline Date & $\begin{array}{c}\overline{C h l} \\
\left(\mu \mathrm{gL}^{\prime}\right)\end{array}$ & $\left(\mathrm{mg} \mathrm{C} \mathrm{m}^{\mathrm{ipp}} \mathrm{h}^{-1}\right)$ & $\begin{array}{l}Z_{p p k} \\
(\mathrm{~m})\end{array}$ & $\left(C \mathrm{Ch}^{-1} \mathrm{~h}^{-1}\right)$ & $\begin{array}{l}\overline{\varepsilon_{1 n}} \\
(m)\end{array}$ & $\left.\left(\mathrm{gCm}^{2} \mathrm{~d} \mathrm{day}\right)^{\prime}\right)$ \\
\hline \multicolumn{7}{|l|}{ Dry season } \\
\hline \multicolumn{7}{|l|}{6 Apr 1990} \\
\hline $7.00-9.00$ & & 63.4 & 0.75 & & 1.9 & 0.91 \\
\hline $10.15-11.45$ & & 47.2 & 0.75 & - & 2.1 & 0.69 \\
\hline $12.10-14.10$ & & 49.1 & 1.25 & - & - & 0.65 \\
\hline Mean: & & 53 & 0.92 & & & 0.75 \\
\hline \multicolumn{7}{|l|}{2 Aрг 1997} \\
\hline $9.35-11.40$ & 27 & 137 & 0.50 & 5.1 & - & 2.1 \\
\hline \multicolumn{7}{|l|}{8 Apr 1997} \\
\hline $8.30-10.00$ & 21 & 220 & 0.70 & 10 & - & 3.1 \\
\hline \multicolumn{7}{|l|}{16 Apr 1998} \\
\hline $10.52-12.17$ & 21 & 239 & 0.63 & 11 & 2.0 & 3.0 \\
\hline \multicolumn{7}{|l|}{22 Apr 1998} \\
\hline $11.01-12.04$ & 20 & 229 & 0.58 & 11 & 1.9 & 3.1 \\
\hline Mean: & 22 & 180 & 0.7 & 9 & 2 & 2.4 \\
\hline \multicolumn{7}{|l|}{ Wet season } \\
\hline \multicolumn{7}{|l|}{301 Oct 1991} \\
\hline $12.20-15.00$ & 14 & 175 & 1.0 & 12 & 1.3 & 2.7 \\
\hline \multicolumn{7}{|l|}{11 Nov 1996} \\
\hline $10.25-13.00$ & 15 & 45.1 & 1.25 & 3.0 & 1.4 & 0.98 \\
\hline \multicolumn{7}{|l|}{30 Oct 1997} \\
\hline $9.10-10.10$ & 18 & 31.4 & 1.0 & 1.7 & 1.1 & 0.50 \\
\hline \multicolumn{7}{|l|}{5 Nov 1997} \\
\hline $9.05-11.05$ & 16 & 30.0 & 1.0 & 1.9 & 1.2 & 0.53 \\
\hline \multicolumn{7}{|l|}{10 Nov 1998} \\
\hline $10.30-11.55$ & 14 & 84 & 0.60 & 6.0 & 1.5 & 1.1 \\
\hline \multicolumn{7}{|l|}{17 Nov $1998 ?$} \\
\hline $10.54-12.04$ & 15 & 118 & 0.25 & 7.9 & 1.5 & 1.8 \\
\hline Mean: & 15 & 80 & 0.9 & 5 & 1.3 & 1.3 \\
\hline
\end{tabular}

$\mathrm{Ch}^{-1} \mathrm{~h}^{-1}$ (Hakrss et al. 1989). If $\mathrm{Chl}$ is considered to be $1 \%$ of $\mathrm{C}$ in the tropics (ERIKson et al. 1998), a specific growth rate of about $0.11 \mathrm{~h}^{-1}$ or 1 day ${ }^{1}$ would be obtained in L. Cocibolca. This is a realistic value, although the maximum value would be about 2 day $^{-1}$ at this high temperature (cf. KLBEDE \& AHLGREN 1996). However, at the maximum growth rate for the entire population, i.e. maximum yield or maximum carrying capacity, a maximum specific growth tate for individual algae can never be expected. Rather, individual algae can be expected to grow at half the maximum growth rate $(0.5$ $\hat{\mu})$ (cf. Ahliren 1988a).
Table 1 shows three primary production measurements performed at about 1 -h intervals on the first sampling date (April 1990). The first measurement was $30-40 \%$ higher than the later measurements. Unfortunately, no chemical data are available for this date. It is, however, possible that a 2 -h exposure time was too long for the later measurements. The phytoplankton probably depleted all the nutrients when the light intensity was greater, i.e. the so called botde-effect (Harris et al. 1989). Another hypothesis is that the algae were not in a stare of balanced growth (cf. AHLGRen 1988b). The algae could have been carbon-limited early in the 
morning, with carbon (DIC) uptake being much faster than growth. When saturation levels were reached in the two later measurements, carbon uptake and growth rates were balanced. The light was also much stronger during the last measurement, pressing the $Z_{\text {opt }}$ from $0.75 \mathrm{~m}$ down to $1.25 \mathrm{~m}$ (Table 1).

L. Cocibolca's moderately high primary production values are similar to those of some large African lakes, e.g. Lakes Victoria, Albert, Tanganyika and Volta (MELACK 1976, HECKY \& FEe. 1981). However, seasonal cycles in phytoplankton production and biomass are thought to be latitude-dependent, with the least variation occurring at low latitudes (LF:TELIER et al. 1993). We present data from only two limited time periods, April and late October to early November. The data recorded to date indicate that the seasonal amplitude in primary production is not very great compared to phytoplankton population densities reported for the tropics by TALLING (1986), three orders of magnitude. Monthly data from at least 2 full years of samples are required before the true seasonal variation of primary production in $L$. Cocibolca can be understood. However, insofar as primary production is controlled mainly by light and hydrographical conditions (FOGG 1965), it is very likely that the variation of primary production is less than one order of magnitude in the tropics. A realistic daily mean value would thus be $2 \mathrm{~g} \mathrm{C} \mathrm{m}^{-2}$ day $^{-1}$ and annual primary production would be about $700 \mathrm{~g} \mathrm{C}$ $\mathrm{m}^{-2}$ year ${ }^{-1}$ in L. Cocibolca. In polluted L. Xolotlán, daily primary production was estimated at 5-7 $\mathrm{g} \mathrm{C} \mathrm{m}^{-2}$ day ${ }^{1}$ (ErlKson et al. 1997, 1998), which is about $2000 \mathrm{~g} \mathrm{C} \mathrm{m}^{-2}$ year-1. The daily primary production values and the albeit limited chemical data places L. Cocibolca as a eutrophic lake on the trophic scale (LIKENS 1975).

A general rule of thumb states that $1 \%-1 \%$ o of the primary production of a body of water can go into fish flesh. The mean of the ratio of fish yield/ $\Sigma \mathrm{A}$ (in C) from data given by MFLACK (1976, Table 1) is $0.35 \%$. Considering the community respiration, this figure should be multiplied by 0.25 . Ocil.ESBY (1977) proposed two equations ([1] \& [2]) for estimating fish yield $\left(Y_{i}\right.$ g d.w. $\mathrm{m}^{-2}$ year $\left.{ }^{-1}\right)$, based on either summer chlorophyll ( $\mathrm{Chl})$ or annual primary production $\left(\Sigma A_{y}\right)$. Additional equations are given by Downing et al. 1990 [3] and KNösche \& BARTHELMES 1998 (Bulon-Vinberg relationship) [4]:

$$
\begin{array}{ll}
\left.\log Y_{i} \text { (d.w. }\right)=-1.92+1.17 \log \text { Chl } & {[1] \text { or }} \\
\log Y_{\text {if }}(C)=-6.00+2.00 \log \Sigma A_{y} & {[2]} \\
\log F P=0.6+0.575 \times \log \Sigma A_{y} & {[3]} \\
Y=14.24+0.056 \times P P(4) & {[4]}
\end{array}
$$

OGLESBY (1977) said that Chl is probably the more reliable estimate of fish yield due to the more accurate analytical methods available at that time. This might not hold true today. However, he also said that annual primary production is the more meaningful of the two phytoplankton measurements in terms of ecosys-

\begin{tabular}{|c|c|c|}
\hline $\begin{array}{l}\text { Fresh weight } \\
\left(\mathrm{kg} \mathrm{ha}^{-1} \text { year }^{-1}\right)\end{array}$ & Conversion factor & Reference \\
\hline $700-70$ & $1 \%-1 \%$ of $\Sigma A$ & Rule of thumb \\
\hline 700 & $1 \%$ of $\Sigma A$ & Ryther 1969 \\
\hline 60 & $0.25 \times 0.35 \%$ of $\Sigma A$ & Melack 1976 \\
\hline 20 & $\mathrm{Chl}($ Eq. 1)* & OGilfsby 1977 \\
\hline 50 & $\Sigma \mathrm{A}_{y}(\mathrm{Eq}, 2)$ & OGlesby 1977 \\
\hline 170 & $\Sigma A_{y}$ (Eq. 3) & Downing et al. 1990 \\
\hline 50 & $\mathrm{PP}(\mathrm{Eq} .4)$ & KNOSCHE \& BARTHEL.MES 1998 \\
\hline
\end{tabular}
tem function. Potential fish yield in $\mathrm{L}$. Cocibolca, as estimated by indirect measurements, is summarized below.

*Means of all chlorophyll data collected from different seasons are used here. Assumptions: $1 \mathrm{~g} \mathrm{C}=2 \mathrm{~g} \mathrm{~d}$.w. or $10 \mathrm{~g}$ fresh weight. 
Most estimates are close to the rule of thumb, $1 \%$ of $\Sigma A$. An educated guess is that the values of $50-70 \mathrm{~kg} \mathrm{ha}^{-1}$ year $^{-1}$ are the most realistic. That means that only about $1 \%$ of the potential fish production was caught in L. Cocibolca in the 1970s. These values agree with estimates from several African lakes, e.g. Lakes Victoria, Tanganyika, Albert, and Volta (MELACK 1976, HECKY \& FEE 1981). However, in order to make more accurate estimates of fish yield values for a lake, food web losses must be taken into consideration as discussed in AHrgREN et al. $(2000)$.

\section{Summary and conclusions}

Lake Cocibolca, the largest lake in tropical Latin America, is an important Nicaraguan natural resource. Thirteen C14 measurements made between the years 1990-1998 show that primary production in L. Cocibolca varied between 0.5 and $3.1 \mathrm{~g} \mathrm{C} \mathrm{m}^{-2} \mathrm{day}^{-1}$. Higher mean values were recorded for the dry season than for the wet season, 2.4 and $1.3 \mathrm{~g} \mathrm{C} \mathrm{m}^{-1} \mathrm{day}^{-1}$, respectively. Different hydrological conditions may be the reason for this difference. During the windy dry season, diatoms were dominant, whereas during the more stable wet season, cyanophytes and chlorophytes dominated the lake waters. The fraction of PAR absorbed by phytoplankton was the same during both seasons. I. Cocibolca's primary production values and limited nutrient data place it as a eutrophic lake on the trophic scale. Potential fish production could be $50-70 \mathrm{~kg} \mathrm{ha}^{-1}$ year ${ }^{1}$.

\section{Acknowledgement}

This work was sponsored by SAREC-SIDA (Swedish Agency for Research Cooperation with Developing Countries). Many thanks to Rafaela SaAvidora for the chlorophyll analyses.

\section{References}

Artl.tiRl:N, G., 1988a: Phosphorus as growth-regulating factor relative to other environmental factors in cultured algac. Hydrobiologia 170: 191-210.

ArilgREN, G., 1988b: Comparison of algal Cl4-uptake and growth rate in situ and in vitro. - Verh. Internat. Verein. limnol. 26: 429-434.

Alitikl:n, I. \& ABrgaz, Z., 1993; Interactions of light, nutrients and stratification regimes in controlling phytoplankton primary production in eutrophic lakes. - Verh. Internat. Verein. Limnol. 25: 506-511.

AHI.gRIN, I. \& AHI.iREN, G., 1976: Vattenkemiska analysme- toder sammanställda for undervisningen i limnologi (Mcthods of water-chemical analyses compiled for instruction in limnology, English translation 1978). - Institute of Limnology, Uppsala, Sweden, 112 pp.

Ahigren, G., Gustarson, I.-B. \& Boherg, M., 1992: Fatty acid content and chemical composition of freshwater microalgae. - J. Phycol. 28: 37-50.

AhtgRen, I., ERIKSOn, R., MontenfGro, S., Morting, I., PACHECo, L. \& VAMMEN, K., 2000: Pelagic food web interactions in Lake Cocibolca, Nicaragua. - Verh. Internat. Verein. Limnol. 27: 1740-1746.

Baninistf.r T. T., 1974: Production equations in terms of chlorophyll concentration, quantum yield, and upper limit in production. - Limnol. Oceanogr 19: 1-12.

Colt, G. A., 1976: Limnology of the great lakes of Nicaragua. - In: THORson, 'T. B. (ed.): Investigations of the Ichthyofauna in Nicaraguan Lakes: 9-15. - University of Nebraska, I.incoln, NB.

Dowining, J. A., Piante, C. \& I.alonde, S., 1990: Fish production correlated with primary productivity, not the morphoedaphic index. - Can. J. Fish. Aquat. Sci. 47: 1929-1936.

Erikson, R., Puim, M., Vammen, K., Crliz, A., ReT\%, M. \& ZAMORA, H. 1997: Nutrient availability and the stability of phytoplankton biomass and production in lake Xoloclán (L. Managua, Nicaragua). - Limnologica 27: 157-164.

Ekikson, R., Hooker, E., Mejla, M., ZtlayA, A. \& Vammi., K., 1998: Optimal conditions for primary production in a polymictic tropical lake (Lake Xolotlán, Nicaragua). Hydrobiologia 382: 1-16.

Focic, G. E., 1965: Algal Cultures and Phytoplankton Ecology.'The Athlone Press, London, 126 Pp.

Harris, G. P., GrifrtTh, l: B. \& Tilomas, D. P., 1989: Light and dark uprake and loss of I4C: methodological problems with productivity measurements in oceanic waters. - Hydrobiologia 173: 95-105.

HECKY, R. E. \& FEE, E. ]., 1981: Primary production and rates of algal growth in Lake 'langanyika. - Iimnol. Oceanogr. 26 : 532-547.

Katunin, D. N., Akimon, V. A., Virzin, N. \& Filitov, V. I., 1983: Investigaciones económicas de pesca de los depositos de agua interiores dela Republica de Nicaragua (el Lago de Nicaragua). - Stencilled report. IRENA/Managua.

Kebedot, F. \& Ahigren, G., 1996: Optimum growth conditions and light utilization efficiency of Spirulina platensis $(=$ Arthrospira fusiformis) (Cyanophyta) from Lake Chitu, Ethiopia. - Hydrobiologia 332: 99-109.

KNosche, R. \& BarThElmes, D., 1998: A new approach to estimate lake fisheries yield from limnological basic parameters and first results. - Limnologica 28: 133-144.

Leteller, R. M., Bidiciare, R. R., HFbel, D. V., Ondrestik, M., WINN, C. D. \& KaRI., D. M., 1993: Temporal variability of phytoplankton community structure based on pigment analyses. - Limnol. Oceanogr. 39: 1420-1437.

Likf.ns, G. E., 1975. Primary production of inland aquatic cosystems. - In: LierH, H. \&. Whittakek, R. H. (eds): 
Primary Productivity of the Biosphere: 314-348. - SpringerVerlag, New York.

Lowe-Mc Connfi.t., R. H., 1987: Ecological Studies in Tropical Fish Communities. - University Press, Cambridge, 382 pp.

MELACK, J. M., 1976: Primary productivity and fish yields in tropical lakes. - Trans. Am. Fish. Soc, 105: 575-580.

Nusch, E. A., 1980: Comparison of different methods for chlorophyll and phaeopigment determination. - Arch. Hydrobiol. Beih. Ergebn. Limnol. 14: 14-36.

OGLESBY, R. T., 1977: Relationships of fish yield to lake phytoplankton standing crop, production, and morphoedaphic factors. - J. Fish. Res. Board Can. 34: 2271-2279.

PUGH, G. J. F, 1973. An evaluation of liquid scintillation counting techniques for use in aquatic primary production studies. -Limnol. Oceanogr. 18: 310-319.

RYTHER, J. H., 1969: Photosynthesis and fish production in the sea. - Science 166: 72-76.

Ruvas, K., 1998: Comportamiento del fitoplancton del Laga Cocibolca (Behaviour of phytoplankton in Lake Cocibolca). - Stencilled report. CIRA/Managua.

TAtLINk, J. F., 1965: The photosynthetic activity of phytoplankton in kast African lakes. - Int. Revue Gesamten
Hydrobiol. 51: 546-621.

'lÁl.LING, J. F., 1986: The seasonality of phytoplankton in African !akes. - Hydrobiologia 138: 139-160.

Tal.ling, J. F., Woon, R. B., Prosser, M. V. \& Baxtfr, R. M., 1973: The upper limit of phorosynthetic productivity by phytoplankcon: evidence from Ethiopian soda lakes. Freshwater Biol. 3: 53-76.

THORSON, T.B., 1976: Investigations of the Ichthyofauna in Nicaraguan Lakes. - University of Nebraska, Lincoln, NB.

WOLNY, P. \& GRYGilereK, E., 1972; Intensification of fish

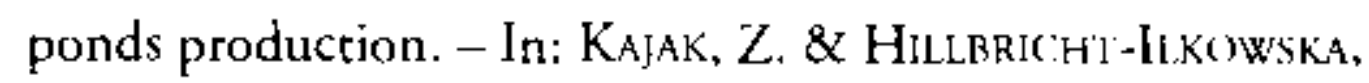
A. (eds): Productivity Problems of Freshwaters: 563-571. Polish Scientific Publishers, Warsaw.

Authors' addresses:

E. Hooker, N. Chow-Wonci, K. Rivas; CIRA/ UNAN, Apartado Postal 4598, Managua, Nicaragua. R. Erikson, I. Ahlgren, G. Ahlgren; Uppsala University, Department of Limnology, Norbyvägen 20 , SE-752 36 Uppsala, Sweden. 